\title{
Yetişkin Yaşam Doyumu Ölçeğinin Geliştirilmesi
}

\author{
Development of Adults Life Satisfaction Scale
}

\author{
IIlker Kaba - Murat Erol - Kadir Güç
}

Başvuru Tarihi: 08.01.2016

Kabul Tarihi: 24.01.2017

\section{Öz}

Bu çalışmada, Türk kültüründe geliştirilmiş olan Yetişkin Yaşam Doyumu Ölçeği (YYDÖ) tanıtılmaya çalışılmıştır. Ölçeğin geçerlik ve güvenirlik çalışmaları toplam 416 yetişkin birey (kadin: 83, erkek: 333) ile gerçekleştirilmiştir. Veriler SPSS 22.0 ve M Plus 7.0 program ile analiz edilmiştir. YYDÖnün yapı geçerliği, açımlayıcı ve doğrulayıcı faktör analizi ile incelenmiştir. Açımlayıcı faktör analizi sonucunda YYDÖ’nün beş faktörlü bir yapı içerdiği ve toplam varyansın \% 65.98'ini açıklayabildiği görülmüş̧ür. Doğrulayıcı faktör analizi sonucuna göre ölçeğin uyum indekslerinin kabul edilebilir düzeyde olduğu belirlenmiştir $\left(\chi^{2} / s d=1.48, T L I=.93, C F I=.94, R M S E A=.063\right.$, $S R M R=.065)$. Ölçüt geçerliği için yapılan uygulama sonucunda ise YYDÖ ile Genel Yaşam Doyumu Ölçe$\breve{g}$ i (Diener, Emmons, Laresen\&Griffin, 1985) arasinda pozitif yönlü ve anlamlı bir ilişki olduğu görülmüştür $(r=.67, p<.01)$. YYDÖnün güvenirlik çalışmasında ölçekte yer alan 21 sorunun cronbach alpha iç tutarlllık katsayısı 89 olarak hesaplanmıştır. Ölçeğin 2 hafta ara ile yapılan test-tekrar test güvenirlik çalışmasında ise pearson momentler korelâsyon katsaylsı $r=.891$ $(p<.01)$ bulunmuştur. Ayrica, ölçeğin madde-toplam korelasyonlarımın 41 ile .67 arasında değisştiği ve t-testi sonuçlarına göre \%27'lik alt-üst grupların ortalamala$r ı$ arasındaki tüm farkların anlamlı olduğu görülmüştür. Elde edilen bulgular YYDÖ'nün geçerli ve güvenilir bir ölçme aracı olduğunu ortaya koymuştur.

Anahtar Kelimeler: Yaşam Doyumu, Yetişkin Birey, Ölçek Geliştirme

İlker Kaba, ikabapdr@gmail.com

Murat Erol, muraterol1980@gmail.com

Kadir Güç, kadirguc1988@gmail.com

\begin{abstract}
In this study, the adults life satisfaction scale (ALSS), developed in Turkish culture, has been introduced. Validity and reliability studies of ALSS have been applied to 416 adults (female: 83, male: 333). The data have been analyzed with the SPSS 22.0 and M Plus 7.0 packages. ALSS' construct validity has been analyzed with exploratory and confirmatory factor analysis. As a result of the explaratory factor analysis, it has been determined that ALSS includes a five factor structure and it explains $65.98 \%$ of total variance. Confirmatory factor analysis indicates that the fit indexes are at acceptable level $\left(\chi^{2} / s d=1.48, T L I=.93, C F I=.94, R M S E A=.063\right.$, $S R M R=.065)$. In the result of the application done for criterion validity, it has been understood that there is positively meaningful relation between ALSS and the General Life Satisfaction Scale(Diener, Emmons, Laresene Griffin, 1985) ( $r=.67, p<.01)$. In the study of ALSS' reliability, Cronbach Alpha coefficient of internal consistence has been found as .89. In the scales testretest reliability study which applied every two weeks, Pearson moment correlation coefficient has been found $r=.891$ ( $p<.01)$. Item-total correlations ranged .41 to .67 , and according to t-test results differences between each item's means of upper $27 \%$ and lower $27 \%$ points were significant. Based on these findings, it's possible to say that ALSS is a valid and reliable assesment evaluation instrument.
\end{abstract}

Keywords: Life Satisfaction, Adults, Scale Development 


\section{Giriş}

19. yüzyılın son yarısına kadar psikoloji biliminde, depresyon ve kaygı gibi olumsuz duygular üzerine yoğunlaşıldığı için olumlu duygular üzerinde durulmamıştır. Son yarım yüzyıldır ise pozitif psikoloji anlayışının gelişmesi ile olumlu duygular ön plana çıkartılmış ve bireyin ruhsal iyi oluşuna yönelik çeşitli kavramlar üzerinde durulmuştur. Bu kavramlardan biri yaşam doyumudur. Yapılan araştırmalar, yaşamdan doyum almanın bireylerin ruh sağlığında olumlu yönde önemli etkiye sahip olduğunu göstermiștir (Diener, 1995; Diener, Horwitz \& Emmons, 1985; Diener \& Suh, 1997; Gündoğar, Gül, Uskun, Demirci \& Keçeci, 2007; Güngör, 2011; Myers \& Diener, 1995; Neugarten, Havighurst\&Tobin, 1961; Özgür, Babacan-Gümüş \& Durdu, 2010; Wan, Jaccard\&Ramey, 1996; Wardle \& diğerleri, 2004).

Doyum, beklentilerin, gereksinimlerin, istek ve dileklerin karşılanmasıdır. "Yaşam doyumu" ise bir insanın beklentileriyle (ne istediği), elinde olanların (neye sahip olduğu) karşılaştırılmasıyla elde edilen durum ya da sonuçtur. Yani kişinin beklentilerinin, gerçek durumla karşılaştııılmasıyla ortaya çıkan sonucu ifade etmektedir (Özer ve Karabulut, 2003). Yaşam doyumu öznel iyi oluş ile ilgili bir kavramdır. Öznel iyi oluşun duygusal ve bilişsel olmak üzere iki bileşeni bulunmaktadır. Öznel iyi oluşun duygusal bileşenini olumlu ve olumsuz duygular, bilişsel bileşenini ise yaşam doyumu oluşturmaktadır (Diener, 1984, 1994; Pavot\&Diener, 1993; Pavot, Diener, Colvin\&Sandvik, 1991).

Yaşam doyumu kavramı ilk kez Neugarten, Havighurst \& Tobin (1961) tarafından ele alınmıștır. Neugarten ve diğerleri (1961) yaşam doyumunu, bireyin beklentileri (ne istediği) ile elinde olanların (neye sahip olduğu) karşılaştırılması sonucu elde edilen durum ya da sonuç olarak tanımlarken, Diener ve arkadaşları ise yaşam doyumunu, bireyin yaşamına ilişkin bilişsel değerlendirmesi olarak tanımlamıştır (Diener, 1984, 1994; Diener, Emmons, Larsen \& Griffen, 1985; Diener, Oishi \& Lucas, 2003). Vara (1999) yaşam doyumunu, kişinin beklentilerinin, gerçek durumla karşılaştırılmasıyla ortaya çıkan bir sonuç olduğunu, yaşam doyumu ile genel olarak kişinin tüm yaşamını ve bu yaşamın çok çeşitli boyutlarını içerdiğini belirtmektedir. Yaşam doyumu denildiğinde, belirli bir duruma ilişkin doyum değil, tüm yaşantılardaki doyum anlaşılmaktadır. Genel olarak bireyin istek ve başarıları arasındaki uyum ne kadar çok ise yaşamdan o kadar çok doyum alınacağı varsayılmaktadır (Diener, Oishi \& Lucas, 2003). Beklentilerin ve gereksinimlerin karşılanması durumunda bireylerde yüksek yaşam doyumu, karşılanmaması durumunda ise düşük yaşam doyumu görüldüğü farklı çalışmalar ile ortaya konulmuştur (Diener, 2000; Diener, Emmons, Larsen \& Griffen, 1985, Oishi, Diener, Lucas \& Suh, 1999). Yaşam doyumu, kişinin bir bütün olarak kendi yaşamının genel kalitesini olumlu olarak değerlendirmesinin derecesidir. Başka bir ifadeyle, kişinin kendi yönlendirdiği yaşamından ne kadar çok hoşlandığıdır ve bu kavram, yaşam ile ilgili olumlu duyguları ifade etmektedir. Yaşam doyumu, yaşamın belirli alanlarından tatmin gibi bir seviyede değerlendirilebileceği gibi yaşamın geneli içinde de değerlendirilebilmektedir. Çünkü yaşam doyumu, yaşam hakkındaki genel duyguları da yansitmakta ve duygusal mutluluğun bir ölçütü olarak kabul edilmektedir (Aşan ve Erenler, 2008). Yaşamlarından memnun olan bireylerin, toplum içerisinde daha uyumlu ve üretken olduğu; yaşam doyumunun, temel olarak o toplumdaki refah düzeyi, sağllk hizmetleri ve eğitim olanakları ile ilişkili olduğu; bireylere verilen eğitim, sağlık ve çevre alanındaki hizmetlerin temel amacının yaşam memnuniyetini artırarak insanları mutlu etmesi gerektiği belirtilmektedir (Diener, 2000; Diener \& Seligman, 2004; Seligman, 2000; Diener \& Suh, 1997). Yapılan araştırmalar, yaşam doyumu yüksek bireylerin her yönden sağlıklı bir yaşama, yüksek düzeyde sosyal işlevselliğe, çevrelerinde daha olumlu sosyal ilişkilere, yaşamları ile uyumlu bir mizaca ve kişisel gelişime açık bir bilişsel yapıya sahip olduğunu göstermektedir (Diener, 1984, 1994, 2000; Diener \& Suh, 1997; Diener vd., 1999). Ayrıca, yaşam doyumu yüksek bireylerin daha etkili problem çözdükleri ve stres oluşturan yaşam olaylarına karşı daha dirençli oldukları bilinmektedir (Huebner, Suldo, Smith \& McKnight, 2004; Kabasakal\& Uz-Baş, 2013; Karatekin, 2013; Matheny \& diğerleri, 2002; Sahranç, 2007). Çeşitli araştırmalarda, yaşam doyumunun sosyo-demografik özellikler, evlilik, kültür, din, sağlık durumu, iş yaşamı, sosyal destek imkânları, maddi imkânlar, çevresel koşullar, yaşam deneyimleri gibi çeşitli değişkenlerden etkilendiği görülmektedir (Chow, 2005; Diener, 1984, 1994, 2000; Diener \& Diener, 2009; Diener, Suh, Lucas \& Smith, 1999; Paolini, Yanez \& Kelly, 2006). Farklı gruplar üzerinde yapılan çeşitli çalışmalarda ise yaşam doyumunun bireylerin kendine yönelik algıları ile pozitif yönde anlamlı ilişkili ol- 
duğu ortaya konulmuştur (Aydıner, 2011; Caprara \& Steca, 2005; Chow, 2005; Diener \& Diener, 2009; Erol, Çelik \& Üçok, 2015; Lightsey Jr \& diğerleri, 2013; Mowrer \& Parker, 2004; Özbay, Palanc1, Kandemir \& Çakıc1, 2012; Telef \& Ergün, 2013; Vecchio, Gerbino, Pastorelli, Del Bove \& Caprara, 2007; Yiğit, 2012).

Yaşam doyumuna ilişkin yurtdışı alanyazında, yetişkin bireyler üzerine yapılan çalışmalarda farklı ölçme araçlarının kullanıldığı görülmüştür. Ülkemizde yapılan çalışmaların neredeyse tamamında Diener, Emmons, Laresen ve Griffin (1985) tarafından geliştirilen ve Türkçeye uyarlaması Köker (1991) ve Yetim (1993) tarafindan yapılan, geniş bir yaş grubuna uygulanabilen ve sadece genel yaşam doyumu hakkında fikir veren "Genel Yaşam Doyumu Ölçeği"nin kullanıldığg görülmüştür (Akandere, Acar \& Baştuğ, 2009; Akgündüz, 2013; Altay \& Avc1, 2009; Ardahan, 2012; Arslan, Çelebioğlu \& Tezel, 2008; Atak, 2011; Bilge, Sayan \& Kabakçı, 2009; Çivilidağ, 2007; Doğan, Eryılmaz \& Ercan, 2011; Eryılmaz, 2011; Eryılmaz \& Ercan, 2011; Karademir, Türkçapar, Ulucan \& Bahadır, 2013; Telef, 2011; Toros, Akyüz, Bayansalduz \& Soyer, 2000; Tümkaya, Hamarta, Deniz, Çelik \& Aybek, 2008; Ünal, Karlıdağ \& Yoloğlu, 2001; Yllmaz \& Altınok, 2009; Yılmaz \& Sümbül, 2009; Yiğit, 2012).

Alanyazında, doğrudan yetişkin bireylere yönelik olan ve yetişkin bireylerin yaşam doyumunu farklı yönleriyle ölçebilen bir ölçme aracına rastlanmamıştır. Ülkemizde alanyazında sıklıkla kullanılan 5 maddelik "Genel Yaşam Doyumu Ölçeği" (Diener ve ark., 1985)'nin soru sayısının az olması ve sadece genel yaşam doyumunu ölçmesi nedeniyle, bireylerin yaşam doyumlarına dair daha ayrıntılı bir ölçek geliştirmeye ihtiyaç duyulmuştur. Bu nedenlerle, yetişkin bireylerin yaşam doyumunu yeni bir bakış açısıyla ölçmek için "Yetişkin Yaşam Doyumu Ölçeğì"nin (YYDÖ) geliştirilmesi amaçlanmıştır.

\section{Yöntem}

\section{Çalışma Grubu}

YYDÖ’nün geliştirilmesinde, Ankara ilinde bulunan Hacettepe Üniversitesi, Ankara Üniversitesi, Kara Harp Okulu ve Gazi Üniversitesi'nde çalışan ve uygulamayı kabul eden toplam 416 yetişkin bireyle (83 kadın; \%19.95 ve 333 erkek; \%80.05) çalışılmıştır. Çalışma grubunun yaş aralığı 26 ile 40 yaş arasında değişmektedir. Araştırmanın çalışma grubu, kolay- likla bulunabilen örnekleme (convenience sampling) yöntemi ile oluşturulmuştur. Kolaylıkla bulunabilen örnekleme yöntemi, yakın çevrede bulunan ve ulaşılması kolay, araştırmaya gönüllü olarak katılmak isteyen bireyler üzerinde yapılan örneklemedir (Erkuş, 2011). Araştırma verileri, 2014 yllı Nisan ve Mayıs ayı içerisinde araştırmacılar tarafindan toplanmıştır. Veriler 427 bireyden toplanmış; ancak 11 birey veri toplama aracında eksik ve hatalı cevaplama yaptıkları gerekçesiyle çalışma grubuna dâhil edilmemiştir.

\section{Ölçek Geliştirme Süreci \\ Ölçek Maddelerinin Oluşturulması}

YYDÖ’nün geliștirilmesi amacıyla, öncelikle ilgili alanyazın incelenmiş ve 45 maddelik ölçek madde havuzu oluşturulmuştur. Daha sonra Psikolojik Danışma ve Rehberlik alanından üç kişilik bir uzman grubun görüşü alınarak ölçeğin 42 maddelik deneme formu oluşturulmuştur. Bu aşama literatürde görünüş geçerliği (face validity) olarak bilinmektedir. Görünüş geçerliliği, bir ölçme aracının adı, açıklamaları ve sorularıyla ölçmeyi amaçladığı özelliği ölçüyor görünmesidir (Büyüköztürk, Kılıç-Çakmak, Akgün, Karadeniz ve Demirel, 2017).

\section{Ön Deneme Aşaması}

YYDÖ’nün 42 maddeden oluşan deneme uygulamas1 53 birey üzerinde yapılmıştır. Deneme uygulaması sonucunda bireyler tarafından çok iyi anlaşılmadığ tespit edilen maddeler daha anlaşılır biçimde yeniden düzenlenmiş ve 2 madde ölçekten çıkarılmıştır. Ölçeğin Likert tipi, beşli derecelendirmeli (Hiç uygun değil=1, Tamamen uygun=5) olması ve ölçekte 4 tane tersine çevrilmiş (reverse) madde bulunması kararlaştırılmıştır.

\section{Ölçeğe Uygulanan İstatistiksel Analizler}

YYDÖ’nün yapı geçerliği açımlayıcı faktör analizi (AFA)ve doğrulayıcı faktör analizi (DFA) ile incelenmiştir. Verilerin açımlayıcıfaktör analizine uygunluğunun değerlendirilmesindeKaiser-Meyer-Olkin (KMO) katsayısı ve Barlett küresellik testi kullanılmıştır. Açımlayıcı faktör analizinde; birbiriyle ilişkili maddelerin bir araya gelerek faktör oluşturması ve faktörlerin daha kolay yorumlanabilmesi amaciyla varimax eksen döndürme tekniği seçilmiştir. Deneme uygulaması sonucunda oluşturulan ölçeğin 40 maddelik uygulama formu ilk gruptan farklı 243 bireye uygulanmıştır. Bu formun uygulanmasından elde edilen veriler üzerinde ölçeğin faktör yapısı ve 
maddelerin faktör yükleri incelenmiştir. İnceleme sonucunda birinci faktörde faktör yük değerleri .30'dan düşük çıkan, faktör yük değerleri farklı faktörlerde birbirine .10 'dan yakın olan ve bir boyutun altında yalnızca 2 sorunun elde edildiği toplam 19 madde ölçekten çıkarılmıştır. AFA sonucunda oluşan faktör yapısını test etmek amaciyla 120 birey üzerinden doğrulayıcı faktör analizi uygulanmış ve sonuçlar aktarılmıştır. Daha sonra, YYDÖ’nün ölçüt geçerliğini test etmek için Genel Yaşam Doyumu Ölçeği ile birlikte 120 bireye uygulanmıştır. YYDÖ'nün ölçüt geçerliğini incelemek için ise pearson korelâsyon analizi kullanılmıştır.

YYDÖ’nün güvenirliği cronbach alpha güvenirlik katsayısı ve test-tekrar test yöntemi ile incelenmiştir. Ölçeğin güvenirlik çalışmaları için öncelikle 21 maddeden oluşan YYDÖ ölçeğine tümüne ve alt boyutlarına ait cronbach alfa iç tutarlılık katsayıları elde edilmiştir. Daha sonra 243 kişilik grup içerisinden 113 bireye 2 hafta arayla ölçek uygulanmış ve test-tekrar test yöntemi ile güvenirliği incelenmiştir. Ayrıca, YYDÖ'nün madde analizleri, madde toplam korelasyonları ve alt ve üst grup ortalamaları dikkate alınarak bağımsız örneklem t-testi ile incelenmiștir.

Sonuç olarak deneme uygulaması için 53 birey, açımlayıcı faktör analizi ve güvenirlik analizi ve alt-üst grupların arasında anlamlı fark olup olmadığını test etmek için 243 birey, ölçüt geçerliği ve doğrulayıcı faktör analizi için 120 birey olmak üzere toplam 416 bireyin cevapları doğrultusunda YYDÖ’nün geçerlik ve güvenirlik çalışmaları tamamlanmıştır.

\section{Bulgular}

$\mathrm{Bu}$ bölümde, YYDÖ’nün geçerlik ve güvenirliğine ilişkin elde edilen bulgular sunulmuştur.

\section{YYDÖ'nün Geçerliği}

YYDÖ’nün geçerliği, yapı geçerliği ve ölçüt geçerliği ile incelenmiştir. YYDÖ’nün yapı geçerliğinin incelenmesinde, açımlayıcı ve doğrulayıcı faktör analizinden yararlanılmıştır.

\section{Ölçeğin Yapı Geçerliği ve Ölçüt Geçerliğinin İncelenmesi}

\section{Açımlayıcı Faktör Analizi}

YYDÖ’nün yapı geçerliği ilk olarak açımlayıcı faktör analizi ile test edilmiştir. Yapı geçerliği için öncelikle verilerin analiz için uygun olup olmadığı incelenmiştir. Verilerin faktör analizine uygunluğu için KaiserMeyer-Olkin (KMO) katsayısının .60'tan yüksek ve Barlett testinin anlamlı çıkması gerekmektedir (Büyüköztürk, 2004). Yapılan analizde, YYDÖ’ye ilişkin KMO katsayıs1 .856 ve Barlett testi anlamlı $(p<.001)$ çıkmıştır. Bu sonuçlar ölçeğe açımlayıcı faktör analizi uygulanabileceğini göstermektedir.

Açımlayıcı faktör analizinde faktör yükü .30'dan düşük olan maddeler, farklı faktörler altında faktör yükleri birbirine .10'dan daha yakın olan maddeler, anti-image matrisinde köşegen üzerinde .50 'den daha düşük değere sahip olan maddeler analize dahil edilmemektedir. Ayrıca bir faktör altında en az üç soru bulunmalıdır; yalnızca bir ya da iki sorunun elde edildiği maddelerden oluşan faktörler de analiz dışı bırakılmalıdır (Yaşar, 2014). Uygulanan açımlayıcı faktör analizi sonucunda faktör yük değeri .30'un altında kalan 12 madde $(1,7,8,11,12,19,20,26,30,31$, $37,38)$, farklı faktörler altında çok yakın faktör yükleri (faktör yükleri arasındaki fark .10'dan düşük) olan 5 madde $(10,14,25,32,35)$ ve bir boyut altında sadece 2 sorunun elde edilebildiği 2 madde $(39,40)$ olmak üzere toplam 19 madde ölçekten çıkartılmıştır. Bu işlemler yapılırken maddeler ölçekten teker teker çıkarılıp yeni faktör yükleri dikkate alınarak açımlayıcı faktör analizine devam edilmiştir. Faktörlerin her bir değişken üzerindeki ortak faktör varyansının (communalities) .33 ile .83 arasında değiştiği görülmüsstür. AFA sonucunda öz değeri (eigenvalue) 1 ya da 1'den büyük olan faktörler önemli faktör olarak değerlendirilmektedir (Büyüköztürk, 2004). YYDÖ'de öz değeri 1'den büyük olan 5 faktör saptanmıştır. Ölçek geliştirme çalışmalarında açıklanan toplam varyansın \%41'in üzerinde olmasının ve maddelerin faktör yüklerinin .32'nin üzerinde olmasının ölçeğin geçerli sayllabilmesi için yeterli olduğu belirtilmektedir (Çokluk, Şekercioğlu \& Büyüköztürk, 2012). YYDÖ’de açıklanan toplam varyansın $\% 65.98$ olduğu, birinci faktörün tek başına varyansın \% 31,57'sini açıkladığ1 ve maddelerin faktör yüklerinin birinci faktörde .40 ile .68 arasında değiștiği görülmektedir. Varimax eksen döndürme tekniği sonrasında birinci faktörün altı maddeden $(2,3,4,5,6,9)$, ikinci faktörün beş maddeden $(13,15,16,17,18)$, üçüncü faktörün dört maddeden $(21,22,23,24$,), dördüncü faktörün üç maddeden $(33,34,36)$; beşinci faktörün üç maddeden $(27,28,29)$ oluştuğu belirlenmiştir. Maddelerin 
içerikleri incelenerek birinci faktör "genel yaşam doyumu”; ikinci faktör, "ilişki doyumu”; üçüncü faktör, "benlik doyumu"; dördüncü faktör, "sosyal çevre do- yumu”; beşinci faktör, "iş doyumu" olarak adland1rılmıştır. Uygulanan açımlayıcı faktör analizine dair sonuçlar Tablo l'de verilmektedir.

Tablo 1. YYDÖ'ye Iliş̧kin Açımlayıı Faktör Analizi Sonuçları

\begin{tabular}{|c|c|c|c|c|c|c|c|c|c|}
\hline \multirow[b]{2}{*}{ Faktörler } & \multirow[b]{2}{*}{$\begin{array}{l}\text { Madde } \\
\text { No. }\end{array}$} & \multirow{2}{*}{$\begin{array}{l}\text { Faktör } \\
\text { Ortak } \\
\text { Varyansı }\end{array}$} & \multirow[b]{2}{*}{$\begin{array}{l}\text { Faktör-1 } \\
\text { Yük Değeri }\end{array}$} & \multirow[b]{2}{*}{ Fak.1 } & \multirow[b]{2}{*}{ Fak.2 } & \multirow[b]{2}{*}{ Fak.3 } & \multirow[b]{2}{*}{ Fak.4 } & \multirow[b]{2}{*}{ Fak.5 } & \multirow[b]{2}{*}{$\begin{array}{l}\text { Cronbach } \\
\text { alfa }\end{array}$} \\
\hline & & & & & & & & & \\
\hline \multirow{6}{*}{$\begin{array}{l}\text { Genel Yaşam } \\
\text { Doyumu }\end{array}$} & 6 & .805 & .684 & .852 & & & & & \multirow{6}{*}{.849} \\
\hline & 3 & .775 & .617 & .832 & & & & & \\
\hline & 2 & .724 & .654 & .791 & & & & & \\
\hline & 4 & .647 & .583 & .768 & & & & & \\
\hline & 5 & .607 & .617 & .724 & & & & & \\
\hline & 9 & .327 & .548 & .343 & & & & & \\
\hline \multirow{5}{*}{$\begin{array}{l}\text { İlişki } \\
\text { Doyumu }\end{array}$} & 17 & .821 & .627 & & .864 & & & & \multirow{5}{*}{.849} \\
\hline & 16 & .530 & .569 & & .860 & & & & \\
\hline & 18 & .825 & .636 & & .855 & & & & \\
\hline & 15 & .791 & .443 & & .675 & & & & \\
\hline & 13 & .365 & .426 & & .484 & & & & \\
\hline \multirow{4}{*}{$\begin{array}{l}\text { Benlik } \\
\text { Doyumu }\end{array}$} & 23 & .698 & .534 & & & .787 & & & \multirow{4}{*}{.774} \\
\hline & 24 & .598 & .474 & & & .730 & & & \\
\hline & 21 & .568 & .404 & & & .720 & & & \\
\hline & 22 & .627 & .572 & & & .698 & & & \\
\hline \multirow{3}{*}{$\begin{array}{l}\text { Sosyal Çevre } \\
\text { Doyumu }\end{array}$} & 34 & .781 & .520 & & & & .854 & & \multirow{3}{*}{.737} \\
\hline & 33 & .828 & .672 & & & & .805 & & \\
\hline & 36 & .762 & .672 & & & & .742 & & \\
\hline \multirow{3}{*}{ İş Doyumu } & 28 & .718 & .479 & & & & & .809 & \multirow{3}{*}{.867} \\
\hline & 27 & .673 & .419 & & & & & .787 & \\
\hline & 29 & .568 & .443 & & & & & .687 & \\
\hline \multicolumn{9}{|c|}{$\begin{array}{l}\text { Açıklanan Varyans: Toplam: } \% 65,988 \\
\text { Faktör-1: } 31,569 \text { Faktör-2: } 12,956 \text { Fakt }\end{array}$} & 0,891 \\
\hline
\end{tabular}

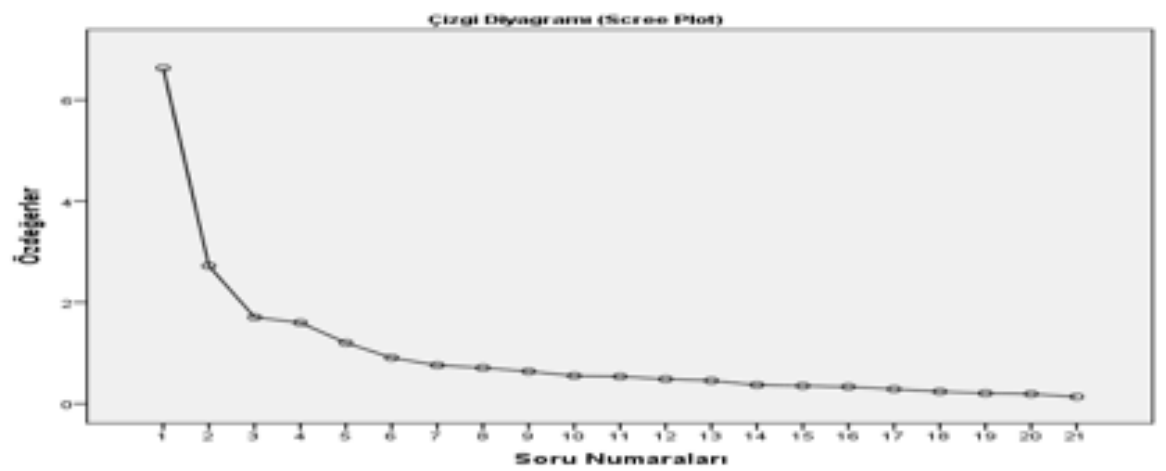

Şekil 1. YYDÖ Çizgi Diyagramı 
Uygulanan faktör analizinin sonuçlarını değerlendirmek açısından kullanılan bir diğer yöntem ise çizgi diyagramının incelenmesidir. Çizgi diyagramında birinci çizgiden sonraki hızlı düşüşs, ortak faktör varyansına ilişkin değerler ve birinci faktördeki yük değerleri göz önünde bulundurulduğunda, YYDÖ’nün beş faktörlü olmasının yanı sıra genel bir faktöre de sahip olduğu düşünülmektedir. YYDÖ’ye ilişkin çizgi diyagramı Şekil 1'de verilmiştir.

\section{Doğrulayıcı Faktör Analizi}

YYDÖ'nün yapı geçerliği ikinci bir yöntem olarak doğrulayıcı faktör analizi (DFA) ile test edilmiştir. Doğrulayıcı faktör analizinde, açımlayıcı faktör analizi sonucu oluşan beş faktör gizil değişkenler; faktörler altında yer alan değerler ise gözlenen değişkenler olarak, modele sokulmuştur. Modelde tüm gizil değişkenlerin birbirleriyle olan kovaryansları da modele dahil edilmiştir. Modelin uygunluğu incelenirken, $\chi^{2} /$ sd, TLI (Tucker-Lewis Index), CFI (Comparative Fit Index), RMSEA (theRoot Mean Square Error of Approximation) ve SRMR (Standardized Root Mean Square Residual) değerleri kritik ölçüt olarak alınmıştır. Maximum Likelihood yöntemi ile gerçekleştirilen doğrulayıcı faktör analizi sonucunda RMSEA değeri .063, CFI değeri .94, TLI değeri .93 SRMR değeri $.065 \mathrm{ve} \chi^{2} /$ sd değeri 1.48 olarak bulunmuştur. Modelin uygun olarak kabul edilebilmesi için RMSEA ve SRMR değerinin 0.08 'den küçük; TLI ve CFI değerlerinin 0.90 ve üzeri; $\chi^{2} / s d$ değerinin ise 5 'ten küçük olması gerektiği bilinmektedir (Browne \& Cudeck, 1993; Hu \& Bentler, 1999; Meydan \& Şeşen, 2011). $\mathrm{Bu}$ modelde TLI, CFI, RMSEA ve SRMR değerleri modelin kabul edilebilir uyumuna işaret ederken, $\chi^{2} /$ sd'nin ise modelin iyi uyumuna işaret ettiği görülmektedir. YYDÖ’ye ilişkin doğrulayıcı faktör analizi bulguları Tablo 2'de verilmiştir.

Tablo 2. YYDö'ye İlişskin Doğrulayıcı Faktör Analizi Sonuçları

\begin{tabular}{lcccc}
\hline Uyum İndeksi & İyi Uyum* & $\begin{array}{c}\text { Kabul Edilebilir } \\
\text { Uyum* }\end{array}$ & $\begin{array}{c}\text { Elde Edilen } \\
\text { Değer }\end{array}$ & Sonuç \\
\hline Ki-kare/sd & $\leq 3.00$ & $3.00 \leq \chi^{2} / \mathrm{sd} \leq 5.00$ & 1.48 & Iyi Uyum \\
\hline TLI & $\geq 0.95$ & $\geq 0.90$ & 0.933 & Kabul Edilebilir \\
\hline CFI & $\geq 0.95$ & $\geq 0.90$ & 0.944 & Kabul Edilebilir \\
\hline RMSEA & $\leq 0.05$ & $\leq 0.08$ & 0.063 & Kabul Edilebilir \\
\hline SRMR & $\leq 0.05$ & $\leq 0.08$ & 0.065 & Kabul Edilebilir \\
\hline
\end{tabular}

* Gürbüz ve Şahin (2016)

Açımlayıcı ve doğrulayıcı faktör analizlerinden elde edilen sonuçlara göre YYDÖ'nün bir ölçek için gerekli olan yapı geçerliği kriterlerini sağladığı söylenebilir.
Gerçekleştirilen doğrulayıcı faktör analizine ait standartlaştırılmış katsayıları içeren model Şekil 2 de aktarılmıştır. Ayrıca, gerçekleştirilen analize ait M Plus komutları ise EK l'de verilmiştir. 


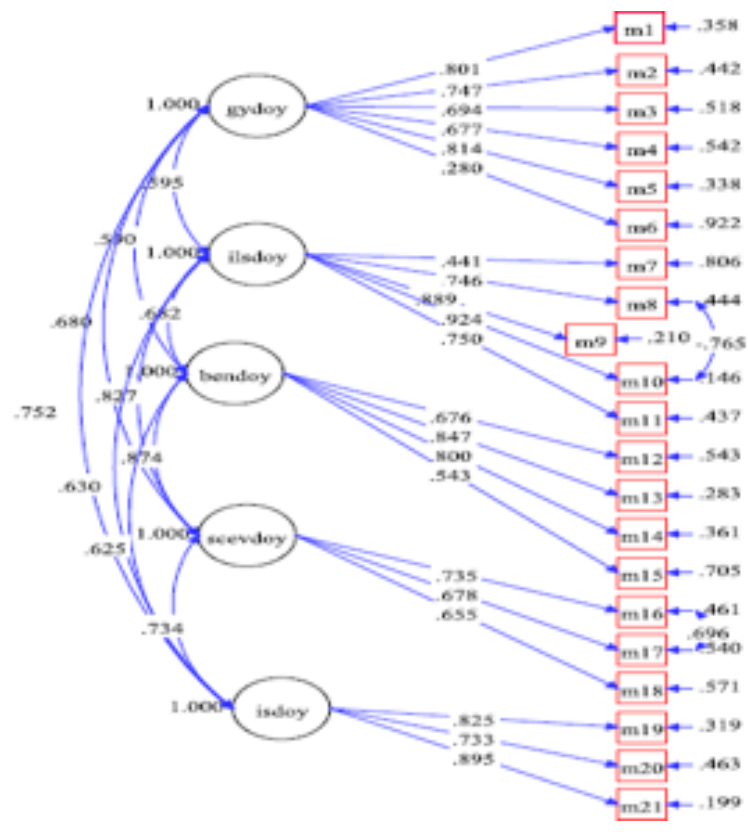

Şekil 2. YYDö'ye ilişkin DFA Modeli

\section{Ölçüt Geçerliği}

YYDÖ'nün yapı geçerliği incelendikten sonra, ölçüt geçerliğini (benzer ölçekler) test etmek için Diener, Emmons, Laresen ve Griffin (1985) tarafından geliştirilen ve Türkçe’ye uyarlaması Köker (1991) tarafından yapilan Genel Yaşam Doyumu Ölçeği (GYDÖ) kullanılmıştır. Ölçek, "yaşam koşullarım çok iyi”, "yaşamımdan hoşnutum" gibi toplam 5 maddeden oluşmaktadır. Ergen bireylerden yetişkin bireylere kadar geniş bir yaş grubuna uygulanabilen likert tipi, yedili derecelendirilen (hiç uygun değil=1, tamamıla uygun=7) ölçeğin toplam puanı 5-35 arasında değişebilmektedir. Ölçekten alınan yüksek puanlar bireyin kendi yaşamıyla ilgili olumlu algılara sahip olduğuna işaret etmektedir. Orijinal çalışmada, ölçeğin Cronbach-alfa iç tutarlılık katsayısı .87; Köker (1991) tarafından yapılan çalışmada ölçeğin Cronbach-alfa iç tutarlılık katsayısı .76; bu çalışmada ise ölçeğin Cronbach-alfa iç tutarlılık katsayısı .90 olarak bulunmuştur. YYDÖ ve GYDÖ birlikte 120 bireye uygulanmış ve yapılan analiz sonucunda YYDÖ ile GYDÖ arasında pozitif ve anlamlı bir ilişki olduğu görülmüştür $(\mathrm{r}=.67, \mathrm{p}<.01)$. İki ölçme aracından elde edilen puanlar arasındaki korelasyon katsayısının pozitif ve yüksek (.05 veya .01 düzeyinde manidar) olmasının, geliştirilen ölçme aracının geçerliğine ilişkin kanıt oluşturduğu belirtilmektedir (Tavşancil, 2010). Elde edilen bu sonuçlara göre YYDÖ’nün bir ölçek için gerekli olan ölçüt geçerliği ölçütlerini sağladığ söylenebilir.

\section{Ölçeğin Güvenilirliğinin İncelenmesi}

YYDÖ'nün güvenirliği, iç tutarlılık (cronbachalfa güvenirlik) katsayısı ve test-tekrar test yöntemi ile incelenmiştir. Bir ölçekte Cronbach Alpha katsayısı; $0.00 \leq a<.40$ ise ölçeğin güvenilir olmadığı, $.40 \leq a<.60$ ise ölçeğin düşük güvenirlikte olduğu,. $60 \leq \alpha<.80$ ise ölçeğin güvenilir olduğu, . $80 \leq a<.1 .00$ ise ölçeğin yüksek derecede güvenilir olduğu belirtilmektedir (Özdamar, 1999). YYDÖ'deki toplam 21 maddenin Cronbach Alpha güvenirlik katsayısı .89 olarak hesaplanmıştır. Boyutların kendi aralarındaki cronbach alfa katsayıları incelendiğinde ise, 6 sorudan oluşan genel yaşam boyutu için $0.849,5$ sorudan oluşan aile ve arkadaş ilişkileri için 0.849 , 4 sorudan oluşan benlik doyumu için $0.774,3$ sorudan oluşan yakın çevre doyumu için $0.737,3$ sorudan oluşan iş ve meslek doyumu için ise cronbach alfa katsayısı 0.867 olarak belirlenmiştir (Tablo 1). Bu sonuçlar cronbach alfa katsayılarının yeterli düzeyde olduğuna ve elde edilen 5 boyut için hiçbir boyuttan madde çıkarılmaması gerektiğine işaret etmektedir. 
YYDÖ, test-tekrar test güvenirliği için 113 kişilik bir gruba iki hafta ara ile uygulanmıştır. Test-tekrar test güvenirlik çalışmasında, güvenirlik katsayısının pozitif ve en az .70 olması beklenmektedir (Tavşancıl, 2010). İki uygulamadan elde edilen puanlar arasındaki pearson momentler korelâsyon katsayısı $r=.891$ $(p<.01)$ bulunmuştur. Elde edilen bu sonuçlara göre YYDÖ’nün bir ölçek için gerekli olan iç tutarlılık ve test-tekrar test güvenirliği kriterlerini sağladığı söylenebilir.

\section{Ölçeğin Madde Analizlerinin İncelenmesi}

YYDÖ'nün madde analizi, madde toplam korelâsyonlarına ve \%27’lik alt-üst grup maddele- rinin arasındaki farklara bakılarak incelenmiştir YYDÖ’nün madde toplam korelâsyonlarının .41 ile .67 arasında değişiklik gösterdiği ve t-değerlerinin bütün maddelerde anlamlı olduğu $(\mathrm{p}<.05)$ görülmektedir. Madde-toplam korelâsyonlarının .30'dan büyük olması ve \%27'lik alt-üst grup madde karşılaştırmaları için kullanılan t-testi sonuçlarının tüm maddeler için anlamlı çıkması ölçekteki maddelerin güvenirliklerinin yüksek olduğunu ve aynı davranışları ölçmeye yönelik olduklarını göstermektedir (Büyüköztürk, 2004). Elde edilen bu sonuçlara göre YYDÖ’nün bir ölçek için gerekli olan madde analizi kriterlerini sağladığ1 söylenebilir. YYDÖ’nün madde analizine ilişkin sonuçlar Tablo 3’te verilmiştir

Tablo 3. YYDÖ'nün Madde Analizi Sonuçları

\begin{tabular}{|c|c|c|}
\hline Madde No & Madde-Toplam Korelâsyonu & $\begin{array}{c}t \\
\text { (Alt\%27-Üst\%27) }\end{array}$ \\
\hline 1 & .649 & $11.24 *$ \\
\hline 2 & .520 & $8.27 *$ \\
\hline 3 & .585 & $8.91 *$ \\
\hline 4 & .601 & $9.97 *$ \\
\hline 5 & .670 & $12.15^{*}$ \\
\hline 6 & .570 & $8.60^{*}$ \\
\hline 7 & .411 & $3.72 *$ \\
\hline 8 & .438 & $6.11^{*}$ \\
\hline 9 & .544 & $7.29^{*}$ \\
\hline 10 & .594 & $7.41^{*}$ \\
\hline 11 & .625 & $8.29 *$ \\
\hline 12 & .434 & $6.24^{*}$ \\
\hline 13 & .562 & 7.94* \\
\hline 14 & .536 & $7.53^{*}$ \\
\hline 15 & .488 & $6.72 *$ \\
\hline 16 & .465 & $6.68^{*}$ \\
\hline 17 & .533 & $8.24 *$ \\
\hline 18 & .493 & $7.52^{*}$ \\
\hline 19 & .651 & $10.03 *$ \\
\hline 20 & .515 & $6.56^{*}$ \\
\hline 21 & .669 & $11.22 *$ \\
\hline
\end{tabular}




\section{Tartışma, Sonuç ve Öneriler}

$\mathrm{Bu}$ çalışmada Yetişkin Yaşam Doyumu Ölçeği geliştirilmiştir. YYDÖ'nün geçerlik ve güvenirlik çalışmalarına ilişkin elde edilen sonuçlar, YYDÖ’nün yetişkin bireylerin yaşam doyumlarını ölçmek amacıyla kullanılabileceğini göstermektedir. YYDÖ'de 1 tanesi tersine çevrilmiş (reverse) olmak üzere toplam 21 madde bulunmaktadır. Ölçek Likert tipi, beşli derecelendirmeli $(1=$ Hiç uygun değil, $2=$ Uygun değil, $3=$ Kismen uygun, 4=Uygun, 5=Tamamen uygun) olarak tasarlanmıştır. Ölçekte 6. madde tersinden puanlanmaktadır. YYDÖ'den alınabilecek puan 21 ile 105 arasında değişmektedir. Ölçekten alınan yüksek puanlar, bireyin kendi yaşamıyla ilgili olumlu algılara sahip olduğu anlamına gelmektedir.

YYDÖ, beş faktörlü bir yapı içermektedir ve birinci faktör, genel yaşam doyumu $(1,2,3,4,5$ ve 6 . maddeler); ikinci faktör, ilişki doyumu (7, 8, 9, 10 ve 11 . maddeler); üçüncü faktör, benlik doyumu (12, 13, 14 ve 15. maddeler); dördüncü faktör, sosyal çevre doyu$\mathrm{mu}$ (16, 17 ve 18. maddeler); beşinci faktör, iş doyumu (19, 20 ve 21. maddeler) olarak adlandırılmıştır. YYDÖ'nün son hali EK-2'de verilmiştir.

Ölçeğe istatistiksel testlerden; yapı geçerliği için açımlayıcı ve doğrulayıcı faktör analizinin yanında ölçüt geçerliği için benzer ölçek geçerliği, güvenirlik çalışmaları için cronbach alfa (iç tutarlılık) katsayıs1 ve test tekrar test yöntemi, madde analizleri içinse madde toplam korelasyonları ve alt-üst grup ortalamaları arası t-testi uygulanmıştır. Analizlerden elde edilen bulgulara göre ölçeğin yeterli istatistiklere sahip olduğu ve geçerlik-güvenirlik koşullarını sağladı$\breve{g}_{1}$ sonucuna varılmaktadır.

Bireylerin yaşam doyumu düzeyinin, temel olarak o toplumdaki refah düzeyi, sağlık hizmetleri ve eğitim olanakları ile ilişkili olduğu; bireylere verilen eğitim, sağlık ve çevre alanındaki hizmetlerin temel amacının yaşam memnuniyetini artırarak insanları mutlu etmesi; başka bir deyişle yaşam doyumunu arttırması gerektiği öne sürülmektedir (Diener ve ark.,2000). $\mathrm{Bu}$ amaçla; rehberlik ve psikolojik danışma (RPD) birimlerinde çalş̧an alan uzmanları YYDÖ'yü kendi amaçları doğrultusunda kullanabilirler. Kamu kurumları ve özel kurumlar kendi çalışanlarının yaşam doyumlarını incelemek ve yapılacak kurumsal düzenlemelerde fikir edinmek için YYDÖ’yü kulla- nabilir. Türkiye İstatistik Kurumu ve özel anket şirketleri de ülkemizde veya farklı ülkelerde yaşayan Türkiye Cumhuriyeti vatandaşlarının yaşam doyumlarına ilişkin yapacakları araştırmalarda YYDÖ’yü kullanabilir. Ayrıca, araştırmacılar da kendi amaçları doğrultusunda YYDÖ'yü kullanabilir. Sonuç olarak geliştirilen ölçeğin bireylerin yaşam memnuniyetini ölçmede alanyazında çok sık kullanılan "Genel Yaşam Doyumu Ölçeği” (Diener ve ark., 1985)'ne alternatif olarak kullanılması ve literatüre katkı sağlaması amaçlanmaktadır.

Çalışmada, bireylere ölçek maddelerinin yanında demografik özellik olarak yalnızca yaş ve cinsiyet özellikleri sorulmuştur. Yapılacak çalışmalarda bireylere ait meslek, eğitim düzeyi, medeni durum gibi başka demografik özellikler de incelenerek bireylerin yaşam doyumları hakkında karşılaştırmalar yapılabilir. Ölçeğin soru havuzu 45 maddeden oluşmaktadır ve uygulanan teknikler ve uzman değerlendirmeleri sonucunda 21 maddelik nihai ölçek elde edilmiştir. İleride yapilacak çalışmalarda soru havuzunun geniş tutulmasının daha nitelikli bir ölçek geliştirilmesi açısından daha sağlıklı olacağı değerlendirilmektedir. Nitekim ölçeğin boyutlarından birinde sadece 2 soru olduğu için ölçekten çıkarılmıştır (39, 40. maddeler). Çalışmada açımlayıcı faktör analizi ve doğrulayıcı faktör analizi için farklı örneklem grupları kullanılmıştır. Yapılan bazı ölçek geliştirme çalışmalarında her iki analiz için de aynı örneklem gruplarının kullanıldığı görülmektedir. İleride yapılacak çalışmalarda bu duruma dikkat edilmesi önem arz etmektedir.

\section{Kaynakça}

Akandere, M., Acar, M. \& Baştuğ, G. (2009). Zihinsel ve fiziksel engelli çocuğa sahip anne ve babaların yaşam doyumu ve umutsuzluk düzeylerinin incelenmesi. Selçuk Üniversitesi Sosyal Bilimler Enstitüsü Dergisi, 22(1), 23-32.http://dergisosyalbil. selcuk.edu.tr/susbed/article/view/268

Akgündüz, Y. (2013). Konaklama işletmelerinde iş doyumu, yaşam doyumu ve öz yeterlilik arasındaki ilişkinin analizi. Celal Bayar Üniversitesi Sosyal Bilimler Dergisi,11(1), 180-204.http://dergipark. ulakbim.gov.tr/cbayarsos/article/view/5000056683 
Altay, B., \& Avc1, İ. A. (2009). Huzurevinde yasayan yaşlılarda özbakım gücü ve yaşam doyumu arasındaki ilişki. Dicle Tip Dergisi, 36(4), 275-282.

Ardahan, F. (2012). Duygusal zekâ ve yaşam doyumu arasındaki ilişkinin doğa sporu yapanlar örneğinde incelenmesi. Pamukkale Journal of Sport Sciences, 3(3), 20-33.http://psbd.pau.edu.tr/article/ view/1062000119

Arslan, S., Çelebioğlu, A., \& Tezel, A. (2008). Kemoterapi alan kanserli hastalarda depresyon ve yaşam doyumunun belirlenmesi. Turkiye Klinikleri Journal of Medical Sciences, 28(5), 628-634.http:// www.turkiyeklinikleri.com/article/tr-kemoterapialan-kanserli-hastalarda-depresyon-ve-yasamdoyumunun-belirlenmesi-51600.html

Aşan, Ö. ve Erenler, E. (2008). İş tatmini ve yaşam tatmini ilişkisi. Süleyman Demirel Üniversitesi İktisadi ve İdari Bilimler Fakültesi Dergisi, Sayı 2, 203-216.

Atak, H. (2011). Yetişkinliğe geçiş yıllarında sigara içme davranışının psiko-sosyal belirleyicileri ve sigara içmenin yaşam doyumu yaşam doyumu ve öznel iyi oluş ilişkisi. Klinik Psikiyatri, 14, 29-43. http://klinikpsikiyatri.org/files/journals/1/2569. pdf.

Aydıner, B. B. (2011). Üniversite öğrencilerinin yaşam amaçlarının alt boyutlarının genel öz-yeterlik yaşam doyumu ve çeşitli değişkenlere göre incelenmesi.(Yayınlanmamı̧̧ Yüksek Lisans Tezi). Sakarya Üniversitesi/Eğitim Bilimleri Enstitüsü, Sakarya.

Bilge, F., Sayan, A., \& Kabakçı, Ö. F. (2009). Aile mahkemesi uzmanlarının meslek doyumları, yaşam doyumları ve ilişkilere yönelik inançlarının incelenmesi. Türk Psikolojik Danışma ve Rehberlik Dergisi, 4(32), 20-31.http://dergipark.ulakbim.gov.tr/ tpdrd/article/view/1058000022

Browne, M. W., \& Cudeck, R. (1993). Alternativeways of assessing model fit. In K. A. Bollen\& J. S. Long (Eds.), Testingstructuralequationmodels(pp. 136162). Newsbury Park, CA: Sage.

Büyüköztürk, Ş. (2004). Sosyal bilimler için veri analizi el kitabi. Ankara: PegemA.
Büyüköztürk, Ş., Kılıç-Çakmak, E., Akgün, Ö. E., Karadeniz, Ş. ve Demirel, F. (2017). Bilimsel araştırma yöntemleri. Ankara: Pegem Akademi.

Caprara, G. V. \& Steca, P. (2005). Self-efficacybeliefs as determinants of prosocial behavior conduciveto life satisfaction acrossages. Journal of Socialand Clinical Psychology, 24(2), 191-217.doi: 10.1521/ jscp.24.2.191.62271

Çivilidağ, A. (2007). Okul psikolojik danışmanlarının psikolojik taciz ve yaşam doyumu düzeylerinin incelenmesi. Abant İzzet Baysal Üniversitesi Eğitim Fakültesi Dergisi, 12(1), 129-144.http://www.efdergi.ibu.edu.tr/index.php/efdergi/article/view/9

Chow, H. P. H. (2005). Life satisfaction among university students in a Canadian prairiecity: A multivariate analysis. Social Indicators Research, 70, 139-150. http://www.jstor.org/ stable/27522159?seq=1\#page_scan_tab_contents

Çokluk, Ö., Şekercioğlu, G., \& Büyüköztürk, Ş. (2012). Sosyal bilimler için çok değişkenli istatistik SPSS ve LISREL uygulamaları. (2.Baskı). Ankara: PegemA.

Diener, E. (1984). Subjectivewell-being. Psychological Buletin, 95(3), 542-575.

Diener, E., Emmons, R. A., Laresen, R. J. \& Griffin, S. (1985). The satisfaction with life scale. Journal of Personality Assessment, 49, 71-75.

Diener, E., Horwitz, J. \& Emmons, R. (1985). Happiness of very wealty. Social Indicators Research, 16, 263-274.doi:10.1007/BF00415126

Diener, E. (1994). Assessing subjective well-being: Progress and opportunities. Social Indicators Research, 31, 103-157.doi:10.1007/BF01207052

Diener, E. (1995). A value based index for measuring national quality of life. Social Indicators Research, 36, 107-127.doi:10.1007/BF01079721

Diener, E. (2000). Subjective well-being, the science of happiness and a proposal for a nationalindex. American Psychologist, 55(1), 34-43.http://psycnet.apa. org/psycinfo/2000-13324-004 
Diener, E., Oishi, S. \& Lucas, R. E. (2003). Personality, culture, andsubjectivewell-being: Emotional and cognitive evaluations of life. Annu.Rev.Psychol, 54, 403-25. http://www.ncbi.nlm.nih.gov/pubmed/12172000

Diener, E. \& Diener, M. (2009). Cross-culturalcorrelates of life satisfaction and self-esteem. E. Diener (Eds.). Incultureandwell-being (pp. 71-91). Netherlands: Springer Diener, E., \& Seligman, M. E. (2004). Beyond moneytoward an economy of well-being. Psychological Science in the PublicInterest, 5(1), 1-31.

Diener, E. \& Suh, E. (1997). Measuringquality of life: Economic, social, and subjective indicator. Social Indicators Research, 40, 189-216.

Diener, E., Suh, E., Lucas, R. E., \& Smith, H. L. (1999). Subjective well-being: Three decades of progress. PsychologicalBulletin, 125(2), 276-302.

Doğan, T., Eryılmaz, A., \& Ercan, L. (2014). İşe bağl1lığın öznel iyi oluş üzerindeki yordayıcı rolü: akademisyenler üzerine bir çalışma. Gazi Üniversitesi Endüstriyel Sanatlar Eğitim Fakültesi Dergisi, 33, 48-57.http://dergipark.ulakbim.gov.tr/esef/article/ view/5000091847

Erkuş, A. (2011). Davranış bilimleri için bilimsel araştırma süreci (3.baskı). Ankara: Seçkin.

Erol, M., Çelik, H., \& Üçok, A. (2015). Öğrenci seçme ve yerleştirme sınavlarına giren ergenlerin "benlik algılarının" ve "yaşam doyumlarının" incelenmesi. Eğitimde Kuram ve Uygulama Dergisi, 11(1), 321345. http://canakkale-onsekiz-mart-universitesi-1. dergipark.gov.tr/eku/issue/5464/74160

Eryılmaz, A. \& Ercan, L. (2011). Öznel iyi oluşun cinsiyet, yaş grupları ve kişilik özellikleri açısından incelenmesi. Türk Psikolojik Danışma ve Rehberlik Dergisi, 4(36), 139-151.http://dergipark.ulakbim. gov.tr/tpdrd/article/view/1058000064.

Gündoğar, D., Gül, S. S., Uşsun, E., Demirci, S., \& Keçeci, D. (2007). Üniversite öğrencilerinde yaşam doyumunu yordayan etkenlerin incelenmesi. Klinik Psikiyatri Dergisi, 10(1), 14-27.http://psikiyatridizini.net/viewarticle.aspx?articleid $=6013$
Güngör, T. (2011). Selçuk Üniversitesi Resim-İş Eğitimi Anabilim Dalı öğrencilerinin kaygı ve yaşam doyumu düzeyleri. (Yayınlanmamış Yüksek Lisans Tezi). Selçuk Üniversitesi Eğitim Bilimleri Enstitüsü, Konya.

Gürbüz, S., \& Şahin, F. (2016). Sosyal bilimlerde araştırma yöntemleri: Felsefe-Yöntem-Analiz. (3.Baskı) Ankara: Seçkin.

Hu, L. T., \& Bentler, P. M. (1995). Evaluating model fit. In R. H. Hoyle (Ed.), Structurale quation modeling: Concepts, issues, andapplications (pp. 76-99). ThousandOaks, CA: Sage.

Huebner, E. S., Suldo, S. M., Smith, L. C., \& McKnight, C. G. (2004). Life satisfaction in childrenandyouth: Empirical foundation sandimplications for school psychologists. Psychology in the Schools, 41(1), 8193.doi: 10.1002/pits.10140.

Kabasakal, Z. \& Uz-Baş, A. (2013). Öğretmen adaylarında yaşam doyumunun yordayıcısı olarak problem çözme becerileri. Eğitim ve Ögrretim Araştırmaları Dergisi, 2(1), 27-35.http://www.jret.org/FileUpload/ks281142/File/03a.zekavet_kabasakal.pdf.

Karademir, T., Türkçapar, Ü., Ulucan, H., \& Bahadır, Z. (2013). Haltercilerde benlik saygısı ile yaşam doyum ve vücut benlik algısı arasındaki ilişsinin incelenmesi. Ahi Evran Üniversitesi Kırşehir Eğitim Fakültesi Dergisi (KEFAD), 14(3), 285-294.http:// kefad.ahievran.edu.tr/archieve/pdfler/Cilt14Sayi3/ JKEF_14_3_2013_285-294.pdf.

Karatekin, H. (2013). Benlik yapılarına göre başa çıkma stratejileri ve yaşam doyumunun incelenmesi. (Yayımlanmamış Yüksek Lisans Tezi). Gazi Üniversitesi Eğitim Bilimleri Enstitüsü, Ankara.

Köker, S. (1991). Normal ve sorunlu ergenlerin yaşam doyumu düzeyinin karşılaştırılması. Yayımlanmamış Yüksek Lisans Tezi, Ankara Üniversitesi Sosyal Bilimler Enstitüsü, Ankara.

Lightsey Jr, O. R., McGhee, R., Ervin, A., Gharghani, G. G., Rarey, E. B., Daigle, R. P., Wright, K. F., \& Powell, K. (2013). Self-efficacy for affect regulation as a predictor of future life satisfaction and moderator of the negative affect-life satisfaction relationship. Journal of Happiness Studies, 14(1), 1-18. 
Matheny, K. B., Curlette, W. L., Aysan, F., Herrington, A., Gfroerer, C. A., Thompson, D., \& Hamarat, E. (2002). Copingresources, perceivedstress, and life satisfaction among Turkish and American university students. International Journal of Stress Management, 9(2), 81-97.doi: 10.1023/A:1014902719664

Meydan, C. H., \& Şeşen H. (2011). Yapısal eşitlik modellemesi AMOS uygulamaları. Ankara: Detay.

Mowrer, R. R., \& Parker, K. N. (2004). Revised multicultural perspective index and measures of depression, life satisfaction, shyness, and self-esteem. PsychologicalReports, 95(3f), 1227-1228.doi: 10.2466/pro.95.3f.1227-1228

Myers, D. G., \& Diener, E. (1995). Who is happy? Psychological Science, 6, 10-19.doi: 10.1111/j.14679280.1995.tb00298.x

Neugarten, B. L., Havighurst, R. J. \& Tobin, S. S. (1961). Themeasurement of life satisfaction. Journal of gerontology, 16, 134-143.doi: 10.1037/a0016777

Oishi, S.,Diener, E., Lucas, R. E., \& Suh, E. (1999). Cross culturalvariations in predictors of life satisfaction: Perspectivesfromneedsandvalues.Personal. Soc. Psychol. Bull., 25, 980-990. doi: 10.1177/01461672992511006

Özbay, Y., Palancı, M., Kandemir, M., \& Çakıcı, O., (2012). Üniversite öğrencilerinin öznel iyi oluşlarının duygusal düzenleme, mizah, sosyal özyeterlik ve başaçıkma davranışları ile yordanması. Türk Eğitim Bilimleri Dergisi, 10(2), 325-345. http://www. tebd.gazi.edu.tr/index.php/tebd/article/view/93

Özdamar, K. (1999). Paket programlar ile istatistiksel veri analizi-I (2. Baskı). Eskişehir: Kaan.

Özer, M. ve Karabulut, Ö. (2003). Yaşlılarda yaşam doyumu. Geriatri, 6(2),72- 74.

Özgür, G., Babacan-Gümüş, A., \& Durdu, B. (2010). Evde ve yurtta kalan üniversite öğrencilerinde yaşamdoyumu. Psikiyatri Hemşireliği Dergisi, 1, 2532.phdergi.org/jvi.aspx?pdir=phd\&plng=tur\&un= PHD-44153
Pavot, W. G., Diener, E., Colvin, C. R., \& Sandvik, E. (1991). Furthervalidation of thesatisfactionwith life scale: Evidenceforthecrossmethodconvergence of well-beingmeasures. Journal of PersonalityAssessment, 57(1), 149-161. doi:10.1207/ s15327752jpa5701_17

Pavot, W., \& Diener, E. (1993). The affective and cognitive context of self reported measures of subjective well-being. Social Indicators Research, 28, 1-20. DOİ :10.1007/BF01086714

Paolini, L.,Yanez, A. P., \& Kelly, W. E. (2006). An examination of worry and life satisfaction among college students. Individual Differences Research, 4(5), 331-339.http://eds.a.ebscohost.com/eds/ pdfviewer/pdfviewer?sid=e3e05a36-c2a3-445ea9b8-6300275df08a\%40sessionmgr400\&vid $=0 \& \mathrm{~h}$ id $=4211$

Sahranç, Ü. (2007). Stres kontrolü, genel öz-yeterlik, durumluluk kaygı ve yaşam doyumuyla ilişkili bir akış modeli.(Yayımlanmamış Doktora Tezi). Gazi Üniversitesi Eğitim Bilimleri Enstitüsü, Ankara.

Seligman, M. E. P. (2000). Positive psychology: An introduction. American Psychologist, 55, 5-14. doi/10.1037/0003-066X.55.1.5

Tavşancıl, E. (2010). Tutumların ölçülmesiyle SPSS ile veri analizi (4. Baskı). Ankara: Nobel.

Telef, B. B. (2011). Öğretmenlerin öz-yeterlikleri, iş doyumları, yaşam doyumları ve tükenmişliklerinin incelenmesi. İlköğretim Online, 10(1), 91108.http://ilkogretim-online.org.tr/vol10say1/ v10s1m8.pdf

Telef, B. B.,\& Ergün, E. (2013). Lise öğrencilerinin öznel iyi oluşlarının yordayıcısı olarak öz-yeterlik. Kuramsal Eğitimbilim Dergisi, 6(3), 423-433.http:// keg.aku.edu.tr/arsiv/c6s3/article6.html

Toros, T., Akyüz, U., Bayansalduz, M., \& Soyer, F. (2000). Görev ve ego yönelimli hedeflerin yaşam doyumu ile ilişkisinin incelenmesi (dağcılık sporu yapanlarla ilgili bir çalışma). Uluslararası İnsan Bilimleri Dergisi, 7(2), 1039-1050.https://www.jhumansciences.com/ojs/index.php/IJHS/article/ view/1473/635 
Tümkaya, S., Hamarta, E., Deniz, M. E., Çelik, M. \& Aybek, B. (2008). Duygusal zekâ mizah tarzı ve yaşam doyumu: Üniversite öğretim elemanları üzerine bir araștırma. Türk Psikolojik Danıșma ve Rehberlik Dergisi, 3(30), 1-18.http://dergipark. ulakbim.gov.tr/tpdrd/article/view/1058000100

Ünal, S., Karlıdağ, R. \& Yoloğlu, S. (2001). Hekimlerde tükenmişlik ve iş doyumu düzeylerinin yaşam doyumu düzeyleri ile ilişkisi. Klinik Psikiyatri, 4(2), 113-118.

Vara, Ş. (1999). Yoğun bakım hemşirelerinde iş doyumu ve genel yaşam doyumu arasindaki ilişkinin incelenmesi. Ege Üniversitesi Sağlık Bilimleri Enstitüsü, İzmir.

Vecchio, G. M.,Gerbino, M., Pastorelli, C., Del Bove, G., \&Caprara, G. V. (2007). Multi-faceted selfefficacybeliefs as predictors of life satisfaction in lateadolescence. PersonalityandIndividualDifferences, 43(7), 1807-1818.doi: 10.1016/j. paid.2007.05.018

Wardle, J., Steptoe, A., Guliš, G., Sartory, G., Sêk, H., Todorova, I., Vögele, C. \& Ziarko, M. (2004). Depression, perceivedcontrol, and life satisfaction in universitystudentsfrom Central-Easternand Western Europe. International journal of behavioralmedicine, 11(1), 27-36.doi: 10.1207/ s15327558ijbm1101_4

Wan, C. K., Jaccard, J. \&Ramey, S. L. (1996). Therelationshipbetweensocialsupportand life satisfaction as a function of familystructure: An analysis of fourtypes of support. Journal of MarriageandtheFamily, 58, 502-513.http://psycnet.apa.org/psycinfo/1997-41406-019.
Yaşar, M. (2014). Eğitimde ölçme değerlendirme dersine yönelik tutum ölçeğinin geliştirilmesi. Journal of Educational Science Research, 4(1), 259-279.

Yetim, Ü. (1993). Kişisel projelerin organizasyonu ve örüntüsü açısından yaşam doyumu. (Yayınlanmamış Doktora Tezi). Ege Üniversitesi/Sosyal Bilimler Enstitüsü, İzmir.

Yılmaz, E. \& Altınok, V. (2009). Okul yöneticilerinin yalnızlık ve yaşam doyum düzeylerinin incelenmesi. Kuram ve Uygulamada Eğitim Yönetimi, 15(3), 451-470.http://www.kuey.net/index.php/kuey/issue/view/59/showToc

Yiğit, R. (2012). Çevik kuvvet görevlilerinin benlik saygıları ile yaşam doyumu ve stresle başa çıkma tutumları arasındaki ilişkinin incelenmesi. Ahi Evran Üniversitesi Kırşehir Eğitim Fakültesi Dergisi (KEFAD), 13(1), 61-75.http://kefad.ahievran.edu.tr/ archieve/pdfler/Cilt13Sayi1/JKEF_13_1_2012_6175.pdf

Yılmaz, E.,\&Sünbül, A. M. (2009). Öğretmenlerin yaşam doyumları ve okullardaki örgütsel güven düzeyi. Journal of QafqazUniversity, (26). 172-179.http:// journal.qu.edu.az/content.php?page $=$ article $\& j_{-}$ id=1004\&s_id=103\&a_id=49 
EK 1: DFA için M Plus Komut Dosyası

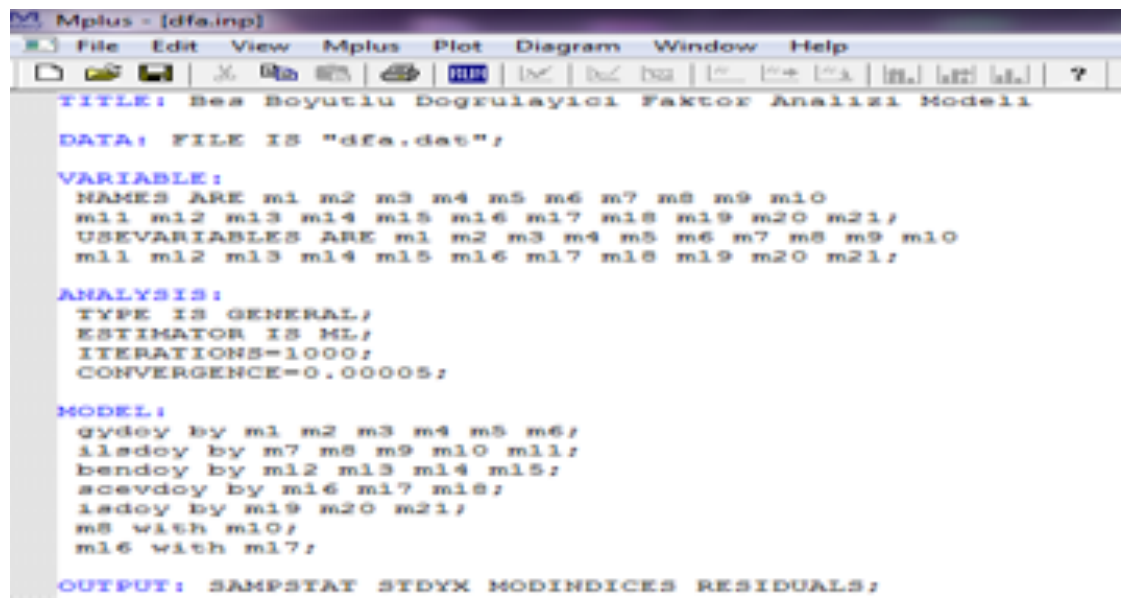

EK 2. Yetişkin Yaşam Doyumu Ölçeği

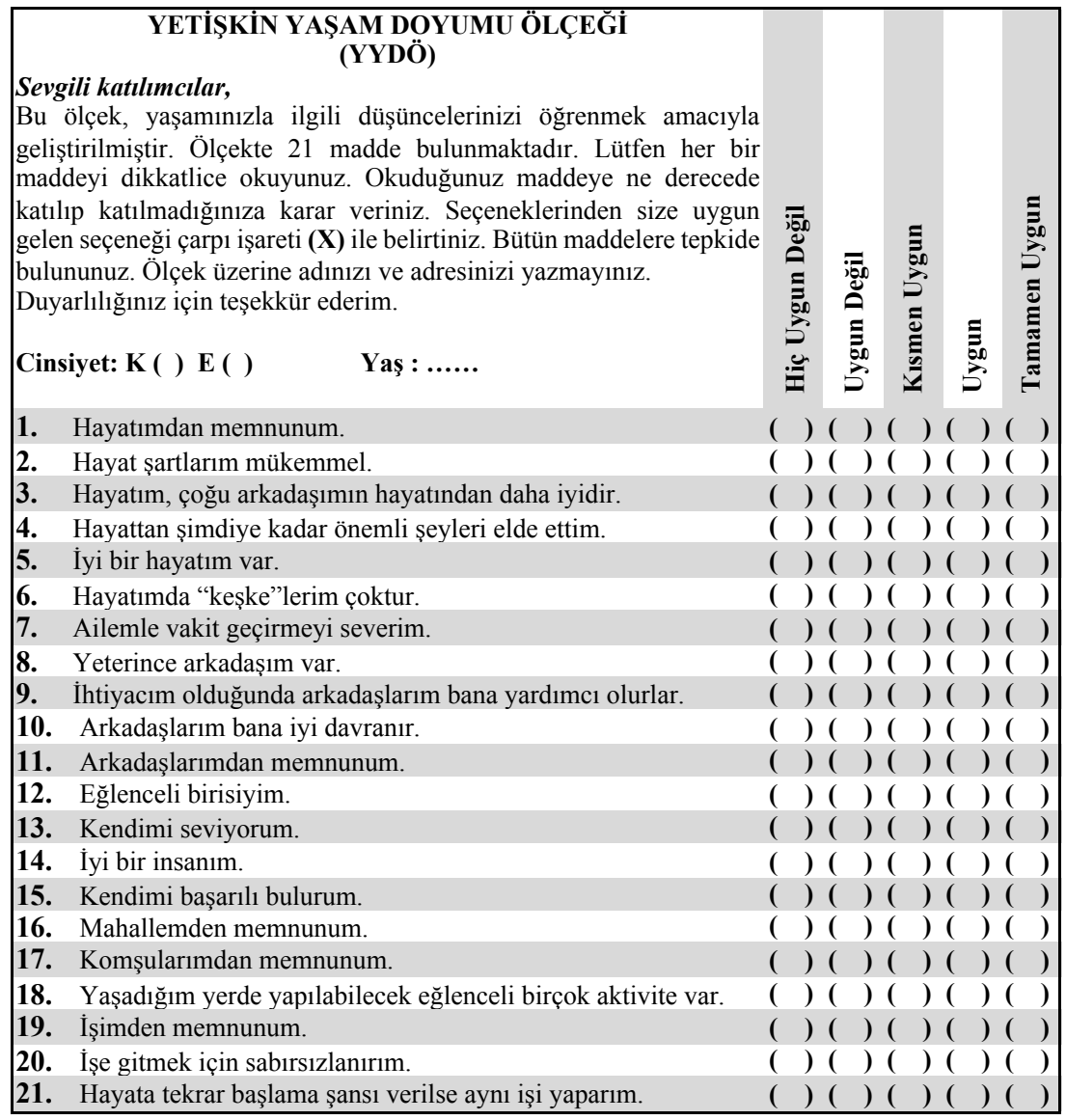

